\title{
Does protection policy actually produce equality among labours? A tentative rules approach to the answers protective problems migrant labour : case migrant labours from East Java, Indonesia
}

\author{
Anita Kristina \\ Department of economics, University of Trunojoyo Madura, Indonesia \\ Email : anita.amanda.ali@gmail.com / anita.kristina@trunojoyo.ac.id
}

\begin{abstract}
Purpose - The purpose of this paper is to analysis effectiveness of the protective rule and their practical effects.

Design/approach - This paper reviews the most important tentative rules and focusing on the principal agent model, which considers the functioning insurance policy to give equality protection. The research has a crucial to analyses the current mechanism of protection policy of cause for disfunction of rules, it actually causes the most orientation to be assumed by labour migran as a principal and the subject of the protection policy. Case study in East Java, Indonesia.

Findings - This mechanism appears theoretically coherent with the protection policy, of equality among labour migran with their performances, but this effect is baced on the benefits of their future performance; this is happened only within their state that their work. The paper concludes that the best effective protection for the labour migran who be a strong protection of the strong coordination actors or the harmonization concepts - by a system of information, professional procedure, capable of reducing as much rules, either pre-existing of the design protection policy.

Value - The paper offers insight into the issue of whether rules protection actually produce equality among migrant labour.
\end{abstract}

Keywords : Protection Policy, Migrant labour right

\section{Introduction}

The protection effort for Indonesian migrant labour is an alternative to create insurance policy for wages transparency, Health, work safety, but it does not focus on law issue only. Thus, the significant point exists on the program functionality, so it needs relevant modified effort without leaving some rules of law through insurance scheme (Simitsia \& kallopi, 2014). In Indonesia, migrant labours get protection on insurance scheme form. All along, The implementation has involved the other actor through the authority delegation of that actor (Private). Indonesian migrant labour as the doer who spends some money for this insurance should has been seen as a subject of that insurance scheme service, and 
government as regulator has been known as a protector and a supervisor of that implementation. Then, the private authority (insurance consortium) is chosen and given mandate by the Indonesian migrant labour and the government to organize its insurance.

The insurance scheme of Indonesian migrant labour is as a government policy in giving protection and also as insurance facility of health and work safety. The implementation goal of this policy depends on the doer who is involved in the process of implementation (Mthethwa, RM, 2012), That is shown by the doer role of that policy and its cooperation pattern (Groenningsaeter \& Riina Kiik, 2012). It also happens in the implementation of this social insurance of indonesian migrant labour, The government gives power and authority to the private authority (insurance consortium). This way is appropriate with the Minister of Manpower and Transmigration regulation in number 7 of 2010 about Indonesian labour insurance.

In the minister regulation, It has been explained that the authority of insurance implementation is insurance company which has license from the Ministry of Manpower and Transmigration, that is insurance consortium which gives service in handling a risk tackling of financial loss, functional loss, and law responsibility to the third side which appears from unsure event, it is related to life or dead of people who guaranteed by it, and compensation fulfilment of insurence by taking action for insured behalf. Meanwhile, as a party which do the operational of placement implementer of Indonesian migrant labour protection is The Natioanal Agency for placement and Protection of Indonesian Migrant Labours, so there are some parties which collaborate in organizing and implementing this policy, those are government as a principal (principal for organizing the insurance of Indonesian migrant labour and social insurance regulator of Indonesian migrant), Indonesian migrant labour as a principal (principal for the amount of money which is paid as a premium form to the insurance consortium) and Insurance consortium as an agent (Implementer and organizer of Indonesian migrant labour insurance).

When doing the research of introduction, it revealed that insurance consortium which has currently covered the Indonesian migrant labour is "Protect TKI", it prevails on July 2013, the insurance of Indonesian migrant labour is organized by 3 (three) consortiums (Jasindo, Astindo, Mitra TKI). The Insurance registration of this Indonesian migrant labour is able through the placement implementer of private Indonesian migrant labour (PPTKIS) or the applicants of Indonesian migrant labour themselves, but it is mostly through placement implementer of private Indonesian migrant labour (PPTKIS). Premium is paid in the beginning that the amount of it based on the article 15 of clause (2) of the Indonesian Minister of Manpower and Transmigration regulation No. Per-07/Men/V/2010 about Indonesian migrant labour insurance, It is mentioned that the premium is about Rp. 50.000 for pre-placement, Rp. 300.000 during placement and Rp. 50.000 for full of placement period. Thus, It is clear that the applicants of 
Indonesian migrant labour will get protection during pre-placement, placement period and full of placement period. Principals which paid by the aplicants of Indonesian migrant labour will be known as insurance when they get accident , and even death. Absolutely, that premium covers all the things which harm the aplicants of Indonesian labour migrant. However, It is often that the insurence does not accomodate the harm of labour aplicants when they are in training period, Such as when they do not get proper training or all the things which are not organized in Insurance contract agreement, that should get insurance in getting training and safety of doing training (Crouch, 2014). All along, Insurance program for Indonesian migrant labour has given very limited protection and it generally covers accident and death insurance only, Whereas, all they need is protection for their selves during working and also for their families who are left (ILO, 2012). It means that the protection which guaranteed by insurance consortium of Indonesian migrant labour is the protection which fulfills pure risk elements, it has meaning that a risk which has financial value is a loss which truly happens based on the amount of paid premium.

This insurance is for all Indonesian migrant labours, however, It is often met some cases that Indonesian migrant labour has not got the true social insurance yet, it is caused by the insurance which given, that only gives a loss which felt by Indonesian migrant labour in pre-placement, placement period, and full of placement. So that, There is still the other social problem that related to fulfill regulation for getting some facilities promised by the insurance. It can happen because there are many parties who do not stand for the Indonesian migrant labour, and there is no coordination with institution that involved in the process of pre-placement, placement period, and full of placement (Azmy, 2012). Whereas, in those three processes, there are many involved actors of institution, those are government as a contoller and implementer of sosial insurance policy, PPTKIS as a partner of government in implementation of pre-placement process, insurance consortium as an organizer of the Indonesian migrant labour insurance, and Indonesian migrant labour as a main actor in giving authority to the insurance consortium for organizing their insurance. Those actors contribute in some mechanisms.

Meanwhile, in the mechanism of social insurance implementation of Indonesian migrant labour still leaves some problems, that main problem is in the effectiveness of this protection to Indonesian migrant labour. thus, the problem which happens in organizing of this Indonesian migrant labour social insurance is in mechanism problem, all along, the insurance company has only prioritized the advantages they get than a service they give (Farbenblum, 2013). Whereas, the management of partnership should not only be provided by economic principals but also by principals to serve (Rossi \& Renato, 2014). This research will explore "does formal rule and the other rules are able to produce the effectiveness of protection policy implementation through equpping of insurance for Indonesian migrant labour?". 


\section{Method}

This research applied phenomenological analysis with perspective of principal and agent theory and also policy theory. Collecting data was done by exclusive interview to Indonesian migrant labour, aplicants of Indonesian migrant labour or ex-Indonesian migrant labour who come from East Java, Indonesia.

\section{Result and Discussion}

\section{Indonesian Migrant Labour Perception to the Effectiveness of Function and the Institution Role of Indonesian Migrant Labour Protection}

Based on the function and the role of institution which manage this Indonesian migrant labour protection managed in the act of No. 39 of 2004, Indonesian migrant labour is seen as an individual who appreciated with the rights on them, it is protected by that act, and based on that act, the Indonesian migrant labour has obigation to protect their self by obligatory buying/ registering their self in the social insurance scheme called Indonesian migrant labour insurance. Additionally, the basic right guaranteed for all people, state through the government and the institution partner has very important function and role. This is very essential for giving insurance of protection for Indonesian migrant labour, especially for contract/agreement that tied among Indonesian labour migrant and PPTKIS, Indonesian migrant labour and consortium, because that agreement is very private so that the access of Indonesian migrant labour protection becomes a need. All along, the access in giving Indonesian migrant labour social insurance service has been given by the government in the insurance scheme that protected in act of No. 39 of 2004, Permenakertrans of No. 7 of 2010 dan its alteration of No. 1 of 2012.

However,the protection given is not whole social insurance because it is only given in financial compensation form. To assess the effectiveness of institution authority which manage this socila insurance, an Indonesian migrant labour stated her disappoinment to the government, this is Retno's statement :

"Where is the government when we get trouble?, if we do not scream out, they will not know. Perhaps, They have many jobs, so we seem as their step children, we are not served well" (Indonesian migrant labour).

so, Indonesian migrant labour is used to get bad service and it has been started since pre-placement, it is caused by many institutions which manage this sosial insurance of Indonesian migrant labour, so Indonesian migrant labour only wants to get satisfaction of service, and they also think that all the things happened are usual. As this following statement of Aeranda :

"It usually happens, we are ignored, they always say that we are foreign exchange heroes but they treat us well if they need, we are used to be screamed out, we are used to be a ball, their duty is not like this, it should be appropriate with each function, is it truly like this?, perhaps, it used to be managed by private company, 
so when they manage it themselve, They can not do it well " (Indonesian migrant labour)

The service of all institutions which involved in the Indonesian labour migrant protection is seen by Indonesian migrant labour as unacceptable things, although they are used to get it but they are not used to handle those all themselves. It used to handle by mitra agents. All along, they can call crisis center if they have problems or suggestion of unsatisfiable thing toward institutions' service which involved in placement and protection of Indonesian migrant labour. By using crisis center provided by government, it should help Indonesian migrant labour to inform all problems that they get, especially placement period. However, in some cases, they choose to not ask for help to the embassy or to not call to the crisis center.

Less of Indonesian migrant labour's trust to the governtment service and their partner can become cause of unawareness to the service given by the government. Many Indonesian migrant labours has got information to call 24 hours crisis center or the other facilities that given if the get trouble, but they prefer to believe in Indonesian migrant labour association of the country they work in. Crisis center service is able to be accessed easily. As a service that receives all lamentations and problems of Indonesian labour migrant, this access needs telephone or internet only. Additionally, iy is not only about untrusted service problem but also accessbilities problem, although they have crisis center. The significant challenge is in telephone or internet service, and also they have limited ability in using telephone or internet, Although they know telephone number that able to call when they get problem, but it can not guarantee to solve their problem. This accessbilities are related to the document completeness, as the following statement of Nur cahyo below :

"I ever wanted to call the Indonesian embassy of Jeddah when I was working there, but I did not know the location of the office, the distance of my place and the embassy office is very far. Finally, I had ridden taxi for 12 hours, when I arrived there, I informed that I was sick but my boss forced me to work continuously, then I ran, but my passport was brought by my boss, so I could not finish my problem at that, even I ever worked in Malaysia, and I got a same case, then the embassy refused to help me, they said that I was illegal migrant labour" (Indonesian migrant labour)

Documentation can be an obstacle of accessibility, the obstacle is unconditional document. Embassy or the other institution which has function to protect has not been able to give maximum service. All problems got by Indonesian migrant labour should become responsibility of those institutions to solve it. However, when confirmed to government through section chief about their protection, the embassy refused to explain that case because they thought that it was a mistake of migrant labour. A good service comes from work quality of the human resource. A service quality depends on official who serves, are they able to work based on 
capcity or they have no quality, so it effects to the service given, although this is an individual problem but it is a part of institution.

\section{Indonesian Labour Migrant Perception to the Effectiveness of Protection Management (Insurance) of Indonesian Labour Migrant}

Although, Insurance program is obligatory program for Indonesian migrant labour, but a program awareness in Indonesian migrant labour environment is still low. They do not know when asked about insurance, Most of them do not know about it. This is the following statement of Nur Cahyo :

"I know about the obligatory insurance only, but I do not understand, what is insurance?, It seems that I do not have that insurance because I do not hold anything, I only know about passport and I have it, I do not know" (TKI / Indonesian migrant labour)

This migrant labour mentioned that there were insurance and it was obligatory, but he did not know the function of it, and he also did not know a form of it. Because of it, the awareness of insurance is not follewed by their enthusiasm to know this insurance program. Moreover, Aeranda told that most of her friends did not think registered insurance in Indonesia, This is the following statement of Aeranda:

"I know many migrant labours, I really know them, they do not know that they register insurance, if they have problem, they come to association, They ask for help, I told to them that we have insurance, but they did not know about it, yeah I knew that they did not know about it, even they do not awareness to register, yeah I know it because all companies has managed it, I also did not know it before, finally I know it some" (Indonesian migrant labour)

The statement of Aeranda told that not all migrant labours have awareness about this insurance program. This ignorance causes a meaningless awareness for them. However, it becomes a note for the government that a low awareness comes from information failure which should been done by PPTKIS, this authority does not explain about the advantages of insurance, so they do not want to copy that document. The biggest obstacle of migrant labout accessibility to the procedure in regestering insurance claim. Although, all of these are managed by PPTKIS, but this obstacle is also caused by Indonesian migrant labour as principal which do not have complite information.

This less information problem causes the adverse selection, it happens because principal is not able to choose qulified principal (Witesman, 2013). Such as, applicants of migrant labour who do not have ability to choose insurance consortium, and government who does not have ability to choose a qualified insurance consortium which appropriate with the government's need (the selection of consortium process is located in the Ministry of Manpower and 
Transmigration centre office area). The selection of agent should base on rationality of election, that is the potential of each actor to act as the principal's need (Graziano, 2015). Based on that statement, Indonesian migrant labour will be a loss side, it is caused by the agent role which wants to get more benefit through giving particular information to the principal (Riaz, et all, 2014). Whereas, All parties that involved in that agreement have mechanism to express all relevant informations with all they need (Suryo \& Agita, 2013), and it does not happen to the Indonesian migrant labour and the government because of less information they have.

This unperfectness focuses on uncomplete information, untransparent, and unclear in explaining to them. That information are also given by asymmetry, so there are only some people who know more than others in same position. Additionally, There is other side who hides that information to get some benefits, and there is also other side who unable and limited to get that information, so that, he / she will be in a loss side, he / she should get all those informations.

The difficulty of claim procedure makes them to be lazy for submitting some claims, they should get compentation for the loss that they got, or they think that they can handle their problem without submitting a claim. It is mentioned by the statement of that migrant labour, the biggest challenge of procedural insurance is when submitting a claim. Lack of awareness and comprehension of insurance and its procedure of that claim becomes a main cause. So that, accessibility to the procedure is very low. The second obstacle is geography factor problem. The offices are located in big cities, and most of migrant labour work in area which has a long distance with the offices.

Most of migrant labour who as informers of this research become critical ones if they are asked to tell about insurance procedure, this criticsm appears because of many informations that they do not know. Insurance submission procedural of Indonesian migrant labour has been managed in the procedure operational standard which had by consortium, so they are able to understand the mechanism of procedural insurance. When a researcher asked to the consortium for the improvement data of claim submission or migrant labour insurance procedure, the answer explained that the mechanism of submission was not for public information, and when the researcher asked to the government about it, The answer said that problem which related to the migrant labour insurance had been on process. They did not explain about detail of mechanism clearly. Researcher did not accept the answer of detail information that related to the procedural mechanism of migrant labour insurance, especially about claim submission.

Low authority control for Indonesian migrant labour and government as principals states that Implementation of migrant labour insurance explicitly depends on the actor. Although, it has managed in the act of No. 39 of 2004, Permenakertrans No. 7 of 2010, and its alteration of No. 1 of 2012 about all institution which has authority of this indonesian migrant labour insurance scheme, and it was 
mentioned that the insurance related to the Indonesian migrant labour protection. A whole implementation is on insurance consortium's hand and also role of mitra agent which dominates for Indonesian migrant labour, so the justice actualization of a role based on the act of No. 39 of 2004 has not yet implemented well.

Thus, protection concept stated in the act of No. 39 of 2004 actually gave base method for the instutions to do their job based on their each authority. At the same time, that act gave conflict space in dividing some unbalance and unfair authorities. The dependence relationship among the actors has shown that there are many spaces to make some conflict among them. Conflict defined by Nugroho (2013) is conflict which seen as a fact. This fact happens in collective life which understood as a competition to get a scarce resource.

The conflict happens to the applicants of Indonesian migrant labour / migrant labour in considering as a side who has a role but it is asked for their responsibility, and also for government as a side who has responsibility to the migrant labour protection. Indeed, some problems appears because dependence of big actors. Finally, it seems that the problems "let to hang them up", those are caused by principal powerlessness to the agent. In this case, especially for about function of government as a "base line of all business" for Indonesian migrant labour should be handled and dominated by the government.

Meanwhile, government "lets" it to be controlled by consortium side (agent) staying in powerlessness of authority with all of obligaton which should be finished. Whereas, for Indonesian migrant labours, Those are controlled by mitra agent staying in powerlessness of financial, but it consists of the obligation to join in the migrant labour insurance by completing the other obligations. It will be complicated conflict. Whereas, conflict will be more complicated if the actor really believes for the powerlessness related to the resources that they have (decision) (Nugroho, 2013). It means that conflict still happens not only related to behalf of problems but also scarcity of resources and value in interacting among the actors. The interaction success among the actors are mostly definited by their capacity to "carry on the conflict" and their ability to "disentangle" the conflict because they want it or not, they has made their own destiny with that conflict, but this suspended actors should realise that conflict which dominated by authoritzation will make them loss (low capacity). However, all interactions work on the corridor which managed in the act or other informal rule.

If this insurance scheme is dealt by management form related to the act of No. 39 of 2004, Permenakertrans of No. 7 of 2010, and its alteration of No. 1 of 2012, it appears a next question. That question is " are the act and that regulation able to guarantee the sovereignty of the whole institution autonomy of each actor ?, but it is only the implementation of act and that ruegulation which consisted of traps caused by interaction of agent to agent, agent to agent's partner or even principal to agent's partner. Finally, those traps have potentiality to appear a conflict, the regulation has a big dependence among the actors, especially for the government 
and the insurance consortium. Meanwhile, the interaction of conflict relation between Indonesian migrant labour and PPTKIS is caused by Indonesian migrant labour powerlessness for the financial and the ability and taking a decision.

Based on that reality, the policy goal among the conflicts can be solved if there is a high standar in level of goal, or minimum risk and failure (although it is found a conflict), that are cost approachment, benefit share, or risk share (Nugroho, 2013). From that nugroho statement, Undirectly, it can be assumed that the policy will be reached, even the purpose of the policy will be stated based on the possibilities which will be received by all actors. It means that the government and the Indonesian migrant labour can spend some money or the other cost as a consequance of a conflict caused by resource powerlessness (financial for Indonesian migrant labour, and information for the government), or there is a transparency in sharing the benefit among the actors. So the goal of Indonesian migrant labour Insurance policy as social insurance implementation of migrant labour is depended on agreement design, although, it will find a conflict among the actors in the implementation of design. The act of No. 39 of 2004 definitely gives traps for the actor authority in organizing indonesian migrant labour insurance. In the detail of identification before, it was found that insurance consortium as strong actor because of their authority that they have, and mitra agent dominated for the information that they have. Whereas, government has limitation in the information resource and the authority that effects to the decission making, and the applicants or Indonesian migrant labours are powerless to give their authority to mitra agent in using their rights to choose and share the things that related to it. Although, Indonesian migrant labours have individual right to choose consortium based on their own choices, but they also have limited capability. They keep staying in powerless side, even the partnership relation in this Indonesian migrant labour is definitely very individual.

Thus, it defines that insurance consortium actor and their mitra have power to give pressure to the Indonesian migrant labour and the government, It is caused by their powerlessness. The center of authority is agent (insurance consortium) and PPTKIS as an estuary of authority for Indonesian migrant labour (it is also as a consortium partner). Those explanations effect to the decision rationality which made by each actor. Each actor take a role based on their behalf, that is maximizing their own utility. Meanwhile, Indonesian migrant labour and the government can only escalade the authority position because of the act of No. 39 of 2004 and the other regulation which stated it, so that it needs to make agreement to make it balance for all parties.

The agreement of collaboration result puts the Indonesian migrant labour to not get position and capability to determine how this agreement made because this agreement has already made by consortium and government will verify it in the next process. Indonesian migrant labour only signs it as a proof to agree this agreement, Although they do not have authority to give their own opinion or give idea about it. Based on the detail and explanation before, so it can be known that 
authority pattern for adaptation among the actorss as a communication pattern related to the need of each actor resource. It means that adaptation of role is needed in the interaction which depends on the owner of the greates number of resources (Insurance consortium), so that needs need adaptation of role with a value that exists in the actor's environment. This difference and clarity of role bring impact to the goal of authority process (communication) in the interaction of actor. The more the difference of role is clear, the more the structure of authority and its value are ambiguous, but the more the interaction process is melting, the more value and its structure are clear. Those dominate altogether for the behalf of every side. It also happens in lobbying process when they get insurance issue, That only insurance consortium has decision authority, so Indonesian migrant labour as the owner of primium money does not bargaining power at the process, and government also can not involve more when it is related to the completion process of Indonesian migrant labour insurance problem. Therefore, The mechanism of principal agent management in giving protection for Indonesian migrant labour is still in coordination form which managed in the informal norms.

Additioanlly, Interaction pattern reflects the structure of authority (North, 1991), It is appropriate with North's statement, so hierarchical coordination pattern also reflects the structure of hierarchical authority, but the interaction pattern is not about hierarchical, it is about collaborative. It means that the authority structure is influenced by dependence of each actor (based on the identification before) which stated that the goal of Indonesian migrant labour insurance policy depends on the quality of the actor who dominates the greatest resource, and the institution environment who involves the actor work in interacting (such as value and norm). It focuses on the adaptation of need among the actors. So the pattern or authority system which currently exists as the output of the interaction intervention among the involved actor.

Finally, some the effectiveness of protection policy problem was identified through Indonesian migrant labour perception for the role and function effectiveness of policy authority institution, and their perception for procedural insurance effectiveness. Based on this following findings, so it can be told that the effectiveness of Indonesian migrant labour pretection policy is not in accordance to the ability of protection policy to give a "truly" protection for Indonesian migrant labour. It happens because of unawareness of Indonesian migrant labour, the protection mechanism still leaves unfair problem of information service, coordination and alteration need of protection design.

\section{Conclusion}

Indonesian migrant labour scheme becomes abligatory scheme which should be paid by the applicants of migrant labour, it is hold by private insurance consortium to give compensation to the applicants of migrant labour or Indonesian migrant labours which get a risk of loss when in pre-placement, placement period, and full of placement. The amount of premium cost which paid in pre-placement period is Rp. 50.000, Rp. 350.000 is for placement period, and 
full of placement period is Rp. 50.000. The total premium cost paid by them is Rp. 400.000 altogether.

However, work plan, institution and insurance procedure of Indonesian migrant labour as a social insurance of migrant labour in the application consists of problem which unappropriate to the act and the other regulation. Firstly, as the people of Indonesia, Indonesian migrant labours are not protected in the act of social insurance, and Indonesian migrant labours are seen differently with the other domestic labour, so in the insurance social, they need specific scheme in outside of current BPJS scheme, that is Indonesian migrant labour insurance scheme.

Technically, Institution work plan of Indonesian migran labour insurance with their procedural insurance consist of many problems, so it makes migrant labour perception related to the that institution service included their awareness, they still do not believe in that service, they also still find some difficulties to the access problem, although they know about crisis center. It is caused by the limitedness of Indonesian migrant labour telephone or internet service and document completeness. However, through the ownership of this insurance, government has protected them from risks which got by them when in pre-placement period, placement period, and full of placement period. The insurance implementation given to the insurance consortium consists of the authority overflow for Indonesian migrant labour insurance management.

The effectiveness of Indonesian migrant labour policy needs coordination of strong institution in the regulation harmonization concept, It consists of information system affirmation, professional procedure, affirmation of some regulations and even affirmation of protection policy design for Indonesian migrant labour.

\section{References}

Azmy, Ana Shabana. Negara dan Buruh Migrant Perempuan. Menelaah Kebijakan Perlindungan Masa Pemerintahan Susilo Bambang Yudhoyono 2004-2010. Yayasan pustaka obor Indonesia. Jakarta. 2012

Crouch, Colin. Introduction: Labour Markets and Social Policy After The Crisis. Transfer: European Review of Labour and Research. Vol. 20. (1). 2014. Pp. 7-22.

Farbenblum, Bassina, Eleanor Taylor Nicholson, Sarah Paoletti. Migrant Workers' Acces To Justice Series. Akses Buruh Migran Terhadap Keadilan di Negara Asal : Studi Kasus Indonesia. Open Society Foundations. New York. 2013. 
Graziano, Mario. Individual and Social Preference Depending The Agent's Perspective Rather Than The Teheoritician's. The Philosophy of The Social Sciences. Vol. 45(2). 2015. Pp. 202-226.

Groenningsaeter, Arne Backer and Riina Kiik, $\mathrm{PhD}$, Implementing social policy social workers' experience from Estonia and Norway. Journal of Comparative Social Work . Vol. 1. 2012. Pp. 1-13.

Mthethwa. R. M. Critical Dimensions for Policy Implementation. African Journal of Public Affairs Vol 5 (2) . 2012. Pp. 1-18.

Nugroho, Riant. Public Policy. Dinamika Kebijakan-Analisis KebijakanManajemen Kebijakan. PT. Alex Media Komputindo. Jakarta. 2011.

North, Douglass. Institutions. The Journal of Economic Prespective. Vol. 5 (1). 1991.Pp. 97-112.

Riaz, Zahid, Sangeetaray \& Pradeep Ray. The Synergistic Effect of StateRegulation and Self-Regulation on Disclouser Level Of Directur and Executive Remuneration in Australia. Administration \& Society. 2014. Pp.1-33.

Rossi, Matteo and Renato Civitillo. Public Private Partnerships: a general overview in Italy. Procedia - Social and Behavioral Sciences. Vol. 109. 2014. Pp. 140 - 149.

Simitsia, Ilektra, Kallopi Kalampoukab. A New Proposal in the Public - Social Insurance System. The Case of Greece. Procedia Economics and Finance. Vol. 9. 2014. Pp. 533 - 538.

Suryo, Robin \& Agita, M Ulfa. Teori Kontrak dan Implikasinya Terhadap Regulasi Pengaduan Barang/Jasa Pemerintah. Jurnal Pengadaan. Vol. 3. 2013. Pp. 1-30.

Witessman, Eva M and Sergio Fernandez. Government Contracts With Private Organizations: Are There Differences Between Nonprofit and For-profits?. Nonprofit and Voluntary Sector Quarterly. Vol. 42 (4). 2013. Pp. 689-715. 